\title{
Possible Socioeconomic Consequences of the Hydropower Dams on the Downstream Communities: Case Study Hatgyi Dam
}

\author{
Kyaw Thu Han \\ Yangon, Myanmar \\ *Corresponding Author: han.kyawthu@gmail.com
}

Copyright(C2018 by authors, all rights reserved. Authors agree that this article remains permanently open access under the terms of the Creative Commons Attribution License 4.0 International License

\begin{abstract}
This research paper examines the possible effects of hydropower dams on downstream communities through a case study of the proposed Hat Gyi dam on Salween River in Kayin State, Southern Part of Myanmar. The purpose of this paper is to find out how local people's livelihoods and ownership of land have been affected by the proposed dam and in what way men and women voice their concerns at the time of the project were being planned and finally to find out the engagement of government authorities or civil societies to the downstream communities of Hat Gyi Dam. I do qualitative method to know the situation properly. The local people believe that the consequences of building the Hat Gyi dam will have effect on their livelihoods and income of the local communities seriously. The dam will have effect on the agriculture production in the region and consequently the regular income of the local people. The local people do not have any chance to raise their concerns, especially women. This paper concludes that although both men and women have lost their livelihood and farmland, women have suffered more due to struggles for daily life. Voice of women cannot be raised during or after the dam has been built due to existing gender discrimination in the society. By analyzing the data I collected from in depth interviews, I conclude that the consequences of hydropower dams would be very bad on local people, especially on women. This socioeconomic impact analysis of a large infrastructure development project provides insight into the unequal relationship among government, construction companies and the local people, the local economy; it determines the portion of the population that benefits and the portion of the population that suffers the cost. By using that insight, I hope policy makers can help to reduce the cost of suffering while without damaging the benefits.
\end{abstract}

Keywords Socioeconomic Consequences, Hydropower Dams, Downstream, Myanmar

\section{Introduction}

The constructions of dams are being proposed in many countries of the Salween river basin. Governments in the South East Asia region are quite eager to build hydropower plants along the river despite the certain and potential negative consequences that will have on local people. Indeed, there should be absolutely no doubt that dams such as the ones being proposed and discussed would negatively impact the living conditions of all the local people living in areas surrounding the projects and downstream of the dams, and in particular women.

My case study is one of the hydropower dams proposed to build on the Salween River called Hat Gyi Dam. It is projected to be built on a section of the Salween River located inside Karen State, Myanmar, relatively close to the Thailand-Myanmar border.

\subsection{Problem Statement}

Myanmar has one of the lowest electrification rates in Asia, less than a third of the population has access to the electricity grid. This is the main reason of the hydropower dam proponents give to the general public when they make big infrastructure projects. In Myanmar, trying to harness the full potential of river basins is the key driving force fueling the construction of new power generation and transmission infrastructure and the exportation of electricity to the neighboring countries such as China and Thailand.

The Myanmar Government has identified 92 potential dam projects to harness up to $50 \%$ of the country's hydropower potential. Hydropower has already affected the natural and social environments of the rivers, and threatens to cause further devastation for local livelihoods as hydropower projects increase in size and number as we can see in other countries. 


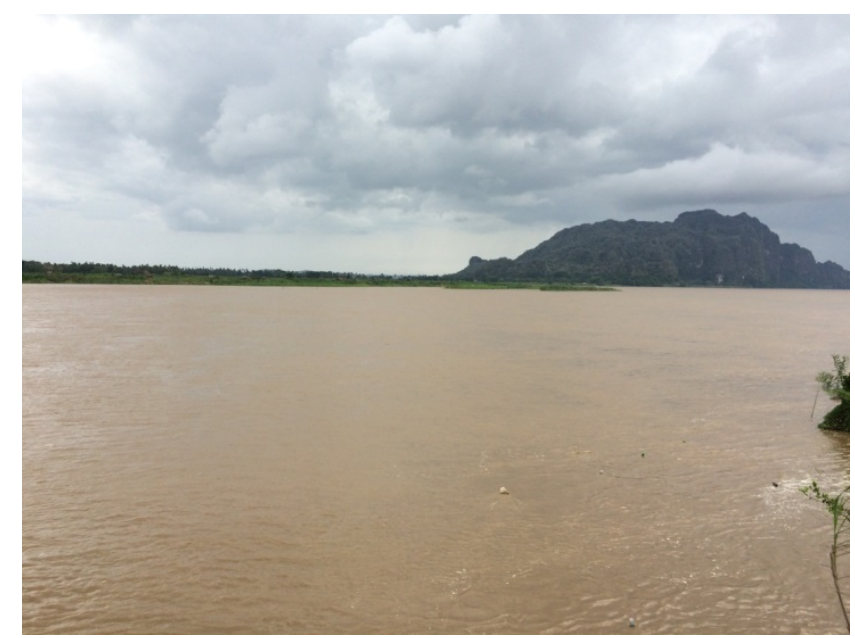

Photo 1. The Salween River, Downstream area of Hat Gyi Dam near the Mi Kayin Village. 31.3.2016 (photographer - Kyaw Thu Han)

There are five large hydropower projects which are being planned along the Salween River Basin in Myanmar. One of the hydropower projects is Hat Gyi Dam which dam site is located in Karen State, a district that has seen high amounts of tension and violence in recent years. The dam project is being funded by the Electricity Generating Authority of Thailand (EGAT), China's Sinohydro Corporation, and Myanmar's Ministry of Electric Power and International Group of Entrepreneurs (IGE). The dam is expected to produce 1,100 to 1,500 megawatts of power, the majority of which will be sent to Thailand. It is located opposite to the Mae Hong Son Province in northern Thailand.

The EIA report for Hat Gyi dam is conducted by Chula Unisearch, Chulalongkorn University. Thailand's Chulalongkorn University was commissioned by EGAT in September 2006 to conduct an Environmental Impact Assessment for the Hat Gyi dam. Despite being paid an estimated 80 million baht by EGAT to do the assessment, the EIA team has been unable to access approximately half of the stretch of river that will be part of the projected flood area as it is under control of the Karen resistance.

However, I could not get the EIA document of the Hat Gyi Dam because the Hat Gyi Dam's Environmental Impact assessment (EIA) has not been made public by Thailand although it is normally obliged to do so by law due to a former nondisclosure agreement signed between EGAT and the Myanmar Hydro Electric Power Department and Myanmar government did not also publish any data. (Page 70-75, E. Zerrouk, Journal of water resources and Ocean Science, 2013).

Dams are a primary example of a large infrastructure project that presents opportunity for economic development, while also engendering environmental changes that consequentially feedback to social and economic values of downstream communities. However, due to limited funding, foreign investments, and arm conflicts in the area cause the dam builders to cut corners leaving socioeconomic impact unaccounted for. With highly valued ecosystems and people who closely rely on the land for their livelihoods, it is important to take all possible consequences into account.

Like all infrastructure development, the Dam may make some benefits to the country of Myanmar, while also placing externalized costs on the local communities supported by the Salween River and the surrounding environment.

\subsection{Main Research Questions}

My major research questions will be "How have their livelihoods and social conditions of men and women living in these areas been affected by Hat Gyi Dam?" I wanted to know how the dam impact on different group of people differently within the small geographic area due to the different socio economic status or gender. Within the local people which groups experience the greatest degree of impact, and how can the analysis of the externalized costs mobilize local communities in future infrastructure decision- making?

This question will be answered by the following sub-investigations, sub-Research Questions:

The sub questions are as followings; I ask these questions and discuss based on these questions.

1. Have you ever heard of the Hat Gyi Dam?

2. Is your attitude toward the Hat Gyi Dam positive or negative?

3. What are the current livelihoods of people living in downstream areas of the Hat Gyi Dam? How much they rely on the Salween River?

4. What is the situation of food security, availability of food, in the area?

5. What is the situation of land ownership in general and women's land ownership?

6. What is the situation of electricity availability in your region?

7. Are you satisfied with the current situation? Why?

8. What will be the greatest impact for both men and women when the dam construction is finished?

9. What will be the livelihood situation in the downstream communities after the dam construction is completed?

10. Do they feel confident about handling of the Hat Gyi dam by the authorities after it will be built?

11. Do you feel threatened by the Hat Gyi Dam's location upstream from your community? And what are your biggest concerns?

12. What is the response from government authorities or other local NGO to listen to the concerns of local people?

13. What would you like the government authorities or NGOs to do for the possible consequences of the dam? 


\subsection{Research Objectives}

By attempting to answer these research questions, I hope that local stakeholders in our country will be increasingly represented in the decision-making for future infrastructure projects. I also hope that both men and women can raise their voices equally related to the potential consequences of the large scale infrastructure projects in their region. To fill the possible information gaps related to the hydropower dam construction on the Salween River.

\subsection{Significance of the Study}

Many researches have been conducted on this region where the Hat Gyi Dam located and its related issues. Most of them are short reports from human rights perspective and water governance. However, most of the researchers often overlooked the potential consequences of dam to the downstream communities. My research thesis mainly focuses on the downstream communities and how different social group suffer differently due to the impacts of the hydropower dam.

The findings of this research will help identify the information gaps between the current research papers and the potential consequences in practice. These results can help the local NGO and INGO to make better strategy to inform people, to help local people raise their concern at the time of large scale infrastructure is built.

Finally, this research can create awareness among policy makers on the issues faced by local people and their worries. And hopefully the policy makers can make proper communication plan to the local people about the future projects and make plan to lessen the worries of the local people about their safety, livelihood and well-being.

\section{Background Context of the Hat Gyi Dam}

In this chapter I want to explain about the history and background context of the Hat Gyi Dam in detail which will make a comprehensive framework for understanding the Hat Gyi Dam project. First of all, I want to explain about the situation of electricity production in our country.

Secondly, I want to talk about my case study Hat Gyi dam project which will include a thorough history of the project, including a timeline charting the plans for the dam, starting from their initial stage.

Myanmar has two major abundant energy resources, namely hydropower and natural gas. The country is one of the five major energy exporters in the region and is the second biggest exporter of natural gas in the Asia Pacific region after Indonesia. However, throughout the country history the governments rely mainly on the hydropower dams for the electrification of the country instead of clean and easy to build Natural gas power plants. The Shweli 1 hydroelectric power plant, with a capacity of $600 \mathrm{MW}$, started operation in 2008. The Yeywa hydropower plant opened in 2010 with a capacity of 790 MW, which is currently the largest one in the country. Several other hydropower projects are under construction or planned. However, planned major hydropower plants have been designed mainly for export. The Myit sone Dam project, with a capacity of $6,000 \mathrm{MW}$, is expected to supply $100 \%$ of its electricity to China, while the Tasang Dam project with a planned capacity of 7,110 MW is planned to supply 1,500 MW to Thailand. And we have four major river basins and its tributaries. So there are so many proposed hydropower dams throughout the country on the numerous river and tributaries.

\subsection{Relation between Hat Gyi Dam and Political Situation of Myanmar}

Like the famous Myit Sone Dam in Northern Kachin State, Hat Gyi Dam in Kayin State is also one of the politically controversial hydropower dams in our country, Myanmar. It is signed and agreed when the country is under the brutal military regime. At those days, people do not dare to confront with the regime directly. So no major protest against the Hat Gyi dam happened during the initial stage of planning the Hat Gyi dam. However, after 2010 election, quasi civilian government led by President Thein Sein took power and had given some political freedom. Then, many local NGOs and activists in the country try to protest the controversial dams including the Hat Gyi dam. Finally, The USDP government led by president U Thein Sein agreed to suspend the Myit Sone dam until next government comes after the 2015 election. And it was not quite clear about other controversial dams along the Salween River.

The location of the Hat Gyi dam is also a major reason of protest against the dam. That area is traditionally controlled by the one of the ethnic armed organizations of our country, Karen National Union (KNU). KNU is a democratic insurgent organization representing the Karen people of Myanmar and retaining control of its own liberated zones. Another major ethnic armed group is called DKBA. In 1994, a group of Buddhist soldiers in the KNLA, citing discrimination by the KNU's overwhelmingly Christian leadership against the Buddhist Karen majority, broke away and established the Democratic Karen Buddhist Army (DKBA). The government want to control the formerly EAO controlled areas. In 2009, Government military and DKBA attack KNU base near the dam site. In this attack, many Karen refugees fled to the Thai and clear the access way to the dam site.

So the government used the Hat Gyi dam project to wage war with local EAOs and controlled the area. In January 2012, U Thein Sein Government signed the initial cease fire agreement with KNU for the first time in 60 years of arm conflict. But only two months after signing the agreement increased numbers of troops were deployed by 
the Burma Army to provide security for the dam builders. The rush to push ahead with this large-scale dam project in Burma's Karen State by private investors is also obstructing the peace negotiations between the KNU and the Burma Army. (internationalrivers.org)

Protest against the hydropower dams also increased during that period. Previously, the KNU had demanded that Hat Gyi Dam should be suspended until political negotiations about peace in Burma finished. However, owing to pressure from the Chinese corporations and EGAT, KNU had to allow the survey of the dam site to proceed. Currently more Burmese troops are being deployed to the western and eastern banks around the dam site. There are now over eight battalions stationed in the area.

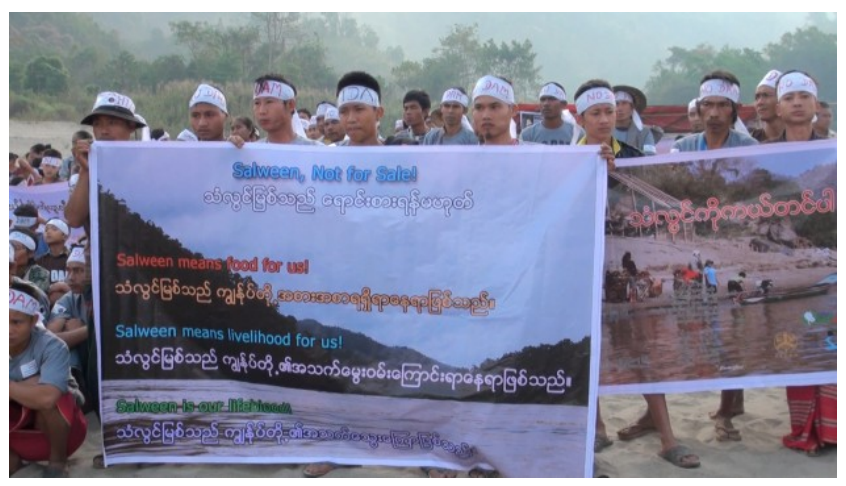

Photo 2. Protest against the hydropower dams on the Salween River basin (source River nations)

\subsection{Detail Information of Hat Gyi Dam}

The Hat Gyi dam is expected to be the first of the planned Salween River dams to be completed but it has not constructed yet. "The Hat Gyi Dam is located in Karen State about 47 kilometers from the Thai-Burma border. The project's investment will come from EGAT International Co and China's Sinohydro Corporation. With an installed capacity of $1,360 \mathrm{MW}$, the project will cost US\$2.6 billion. The project has drawn opposition from local people on both sides of the border of Thailand and Myanmar." (International rivers)

The Hat Gyi dam's site is located in Karen state's Hlaing Bwe Township in Hpa-an District, Myanmar. It is located in the arm conflicts area between Myanmar's military and local ethnic armed organization Karen National Union (KNU). Some environmental and local ethnic groups assume that the government proposed to build Hat Gyi dam at that site because it wants to take control of the region and want to remove the ethnic armed groups residing in the region.

The Hat Gyi Dam project is a joint venture, including numerous public and private stakeholders from Thailand, China, and Myanmar. Involved parties include the state-owned enterprise Electricity Generation Authority of Thailand International (EGAT), the Chinese Sinohydro Corporation, the Myanmar government-controlled Department of Hydroelectric Power Planning (HDPP), and the Myanmar private investment entity International Group of Entrepreneur Company (IGOEC).

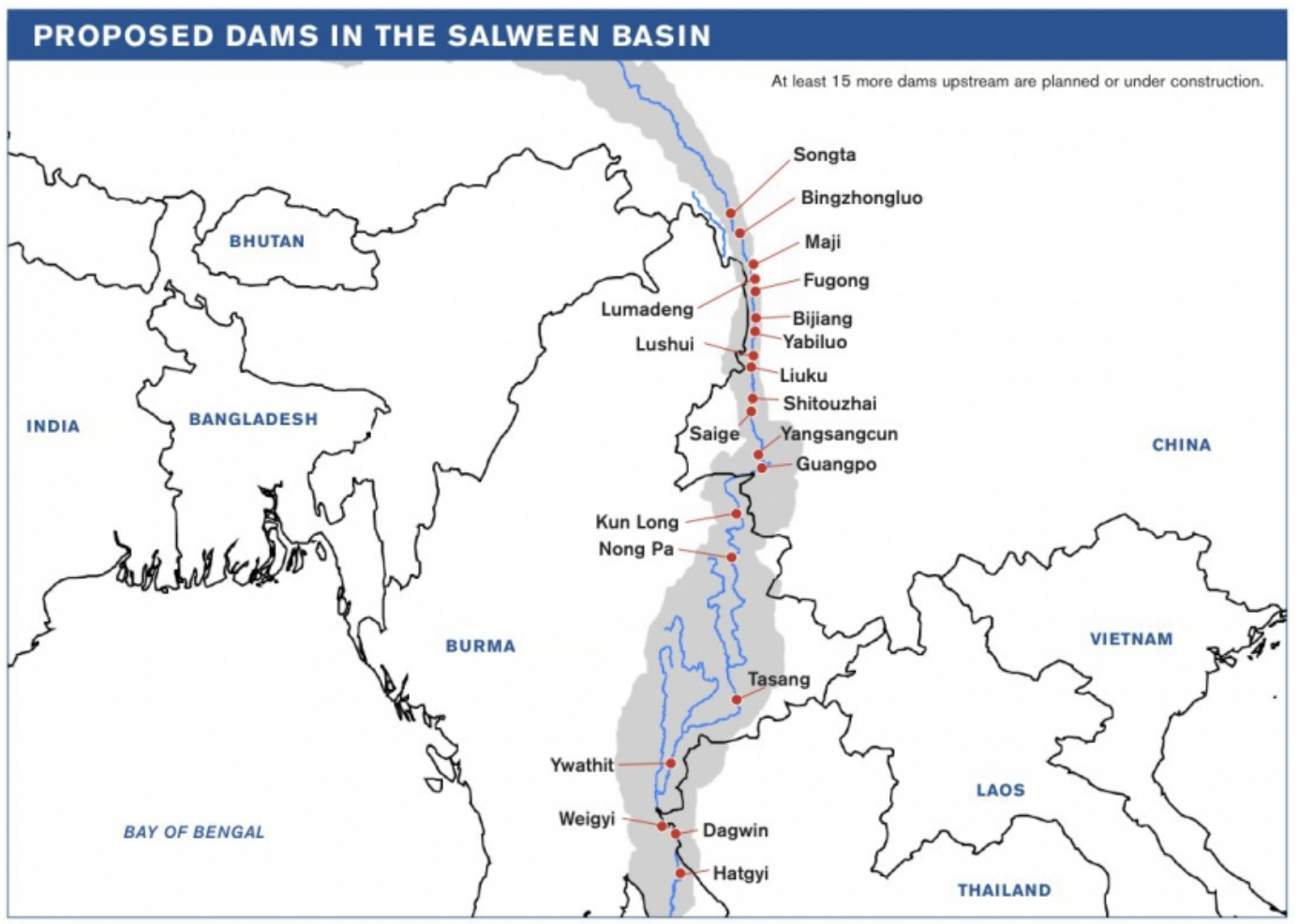

Figure 1. Map of the proposed dams on the Salween River including the Hat Gyi Dam which located in Hlaing Bwe Township, Hpa-an District, Kayin State (Photo taken from https://www.internationalrivers.org/resources/the-salween-river-basin-fact-sheet-7481) 
The life of the project began in 1998 with the start of a pre-feasibility study entitled the "Preliminary Feasibility Study of Hut Gyi Hydropower Project in the Union of Myanmar." The study was carried out with the involvement of Myanmar Electric Power Enterprise (MEPE), the Japanese Marubeni Corporation, the Italian-Thai Development Plc. Co., Ltd., and NEWJEC Inc., the consulting group and subsidiary of Japan's Kansai Electric Power Company. Chula Unisearch from Chulalongkorn University conducts the EIA report for Hat Gyi dam. Thailand's Chulalongkorn University was commissioned by EGAT in September 2006 to conduct an Environmental Impact Assessment for the Hat Gyi dam. However, the conduct of EIA was never fully accomplished due to the current arm conflicts in the region. In May 2006, an EGAT surveyor wounded and died by a land mine while working at the Hat Gyi Dam site. A forum on "Stop All Mekong and Salween dams: Stop All Development Injustice and Human Rights Abuses on International Rivers" is held as part of the ASEAN People's Forum in Hanoi, Vietnam on 18 February 2009. On 24 April, 2010 EGAT International, a subsidiary of EGAT, signs MOA with Myanmar's Department of Hydro-power Planning, Sinohydro Corporation, and International Group of Entrepreneur Co., Ltd. in Nay Pyi Taw, Myanmar. The extent of consultation to date is just EGAT and Unisearch held a meeting to consider a framework that would include more public participation for the additional study on Hut Gyi Dam's environmental impacts at Mae Hong Son city hall.

Public hearings regarding the construction of the dam were held in the Sop Moei District of northern Thailand in 2011. Attendance was high. In December of that year, the Karen National Union reluctantly agreed to allow further surveys to be conducted for the dam. In January of the following year, a temporary ceasefire was signed between the national army and the KNU. Only two months later, however, there was a noticeable build-up of army troops in the area around the dam site.

\subsection{Current Situation Concerning about the Future of Hat Gyi Dam}

After the historic election of November 2015, new civilian NLD government led by Daw Aung San Suu Kyi has taken power from April 2016. Nevertheless, the NLD government do not make any information public about controversial dams across the country although it has repeatedly promised to show these data to the public at the time of 2015 election campaigning.

According to Myanmar's 2008 constitution, new government will have to implement all of the mega projects agreed by the previous government. Therefore, the new civilian NLD government has to deal with these complicated infrastructure agreements. It has to comply with these agreements in any decision making over the Salween River dams. In this research, when I interviewed with local villagers, many people believed that new government had already stopped all the controversial dams including the Hat Gyi dam. In reality, the status of Hat Gyi is still in gray stage and is not clear to both general public and international stakeholders.

\section{Literature Review}

Humans have been shaping the Earth's landscape since the beginning of our existence. In the same way that trees are cut down to make way for roads, dams have been built to manipulate and divert water bodies for human benefit. And Myanmar as a developing country needs many electricity generation projects and it needs to harness the water resources.

However, in Myanmar most of the proposed hydropower dams on the Salween river basin are controversial because they do not consider about the impacts of these dam on the indigenous people living in these areas for many generations. Indigenous peoples have the right to their special and important spiritual relationship with their lands, waters, and natural resources, and to pass these rights to future generations. They have the right to own and develop these lands and resources, in accordance with their traditions and customary laws. Indigenous peoples also have the right to be compensated when their lands, territories or natural resources have been confiscated, occupied, or damaged. These rights are now already recognized in the National Land Use Policy (NLUP) adopted in the Myanmar Parliament.

"However, when local people face displacement due to large scale construction of dams which can cause huge environmental damage, the relation between social impacts on the people and environmental impacts on the ecology and water, their rights described in the National Land Use Policy are not protected. Local indigenous people did not receive enough compensation or other benefits for their losses of land and livelihoods. "Local people living in the dam construction area also suffered forced displacement and environmental destruction and loss of their heritage areas." (KHRG report, "With only our voices, what can we do?")

\subsection{An Overview on the Impacts of Hydropower Dams on Man and Women}

"Villagers described a multitude of consequences as a result of land confiscation, most prominently, livelihood issues, environmental destruction, displacement, and health issues. These consequences were often felt in tandem with one another, compounding the difficulties that local communities faced." (page.8, KHRG report, "With only our voices what can we do?")

Current literatures on gender and environment are doing separately and do not suggest the coherent policy 
framework for both man and women. Since there is another stereotype in our country that farming is the male oriented job, it is not the women's job. Indeed, there are lots of women working in the agriculture sector and are making great contribution to the farming economy.

The impacts of building dams do not fall equally within a population. Due to the existing socio- economic conditions and gender inequality, women face disproportionate impacts of the dams.

In the current draft law about Land, namely the national Land Use Policy, the law did not address the gender discrimination problems but such already unequal situation will aggravate the plight of women when the big scale dams projects constructed along the Salween river.

Therefore, I want to make clear what kind of effective approaches should use to integrate gender in accessing the impacts of dams on the local people. So my study has several interesting dimensions. It focuses on an issue that has not received due attention sufficiently; the Large scale environmental and social impacts of dams, especially on women.

Since the erroneous and prevailing wrong assumptions of the gender discrimination phenomenon can have critical consequences for designing of policy interventions of local NGOs and INGOs aimed to correct it, I expect my research to have a major influence on the way public policy is designed in Burma.

Failure to consider both women's and men's concerns in the design and implementation of social impact assessment (SIA) programs are likely to lead to overlooking the true costs of disasters and making such SIA less effective. Gender-blind responses can also reinforce, perpetuate and increase existing gender inequalities, making bad situations worse for women and other vulnerable groups.

Women can make a difference in social impact assessment (SIA) programs by making efforts through participation and empowerment in the planning, decision-making and implementation processes. However, women participation alone will not solve the problems of gender discrimination because even women do not aware that there are huge gender inequalities prevailing in our society. They also feel normal and accept the situations which are harmful to them. The conventional wisdom is people already accept and acknowledge the gender inequality and want to improve the women conditions participation in decision making, planning, implementation process, etc.

Social norms in Myanmar, developed over time, depict women as weak and in need of protection, the home-makers and preservers of culture and tradition; and men as strong, the breadwinners, decision makers, and leaders. Such stereotypes are accepted generally not only by men but also by women.

Therefore, in my opinion, what is necessary now is to find out with more evidences and stories is whether the local organizations and local people fully understand the gender discrimination in their respective regions.

Gender equality means both women and men should enjoy all human rights regardless of situations, while acknowledging differences between women and men. Preferably, States should ensure that women and girls have equal rights and access. However, if state fails to provide it, local NGOs and INGOs should provide it. From this point of view, we need to know about the impacts of large scale dams on the women, on their livelihood etc., and then we can provide equal access to the women.

Although we do not have enough findings about the impacts of large scale dams on women, we know about the impacts of disasters on women.

So the findings of this research will supply insights for design, implementation of humanitarian projects and critical entry points for integrating gender concerns in policy development for INGOs. Researchers and operational staffs of NGOs and CBO will be interested in knowing the specific impacts of dams on women.

\subsection{Critique of Existing Policy}

A big problem that's often overlooked with the socioeconomic impacts of hydropower dams is the attitude of the government authorities.

The current policy of government is based on the assumption that the government owns every land and water and resource in the country. It is mentioned bluntly in the 2008 constitution.

So the government usually thinks that it is justified to grab land from the local people and build the development projects such as dams for the greater benefits of the country.

The current approach for the loss of livelihoods and land and potential loss of livelihood in the downstream areas are just giving lump sum of certain amount of money to the local families as a way of giving compensation.

Another problem with the current policy is the focus on the local people who live in project site area. While best practice generally recommends giving compensation enough to the local people who are removed from their villages, it fails to recognize the plight of downstream areas and potential impacts on those communities.

Communities are centered around rivers and other bodies of water because they rely on the water as a resource. A dam interrupting a river leads to unpredictable social impact. The downstream communities of Hat Gyi dam rely on the Salween River as their major source of livelihood. The current situation for them is very satisfactory and they worry so much about the possible socio economic impacts of the dam on them. Their livelihoods such as farming and fishing will be affected by the proposed dam construction. Besides, they do not have any place or platform to voice their concerns. They do not have the proper channel to communicate with the policy makers or the respective government authorities. 
One of the hydropower projects is Hat Gyi Hydropower is an example of development that benefits some at the expense of others, and gender is one such variable that is often overlooked.

Since there are knowledge gaps and policy failures to include the possible changes produced by the Hat Gyi dam and concerns of local people, I hope my research will give stimulate policy makers and other stakeholders to consider how to prevent such problems.

\section{Research Methodology}

Socioeconomic analysis can be completed with a variety of tools. In this case, the socioeconomic impact analysis is proactive, and the research aimed to quantify the perceived impact that will occur if the dam project will be fully completed.

\subsection{Research Tools}

This research uses both primary and secondary sources of information. Overall, the study is based on analysis using qualitative research methods, with a combination of focus group discussions with communities inside Karen State, in-depth interviews with potentially affected community members, interviews with key informants, and secondary database research.

Field research was conducted by interviewing diverse key informants, including three village heads, pastor, elders of these villages likely to be affected by construction of the Hat Gyi Dam, local civil society groups, and NGO members such as Karen Human Rights Group (KHRG). Those interviewed were selected based on their knowledge and relevance to the study.

In addition, to corroborate the reliability and validity of primary research data and findings, secondary research was conducted using academic literature, government documents, NGO research reports, and relevant websites.

Field interviews were conducted in Burmese and Karen languages. As the majority of the communities living are ethnic Karen and many local residents speak only Karen, in some cases the researcher used a translator.

In this research I used qualitative technique, i.e. interviews with individuals and small group discussions as research tools. I prepared a set of questions but do not give to the people but I just read it and ask the people every time I interview or make group discussions.

The methods and study design will be mainly base on qualitative approach of primary data and its analysis. It includes individual interviews, and focus group discussion. Secondary data may also be used with online research in any case of limited access to some primary information.

This research was conducted in downstream communities of Hat Gyi dam, which is four villages in two townships in Kayin state namely Hline Bwe Township and Hpa-an Township from end of May to earlier weeks of June, 2016. The four villages are Tandaroo, Kauku, Mine $\mathrm{Ku}$ and Mi Kayin villages. The number of households in Tadaroo village is 256 , in Kauku village is 207, Mine $\mathrm{Ku}$ village is 135 and Mi Kayin is 476. (Source: village heads of these villages).

The total number of correspondents is 82 and four in five of them $(80 \%)$ are currently living in the downstream areas. The remaining $20 \%$ are people who are working in NGO such as KESAN and Karen Human Right Group (KHRG) who are currently living in Yangon or other parts of the country. I wrote down my questions in a sheet of papers to ask in individual interviews or focus group discussions and ask them verbally and recorded their responses.

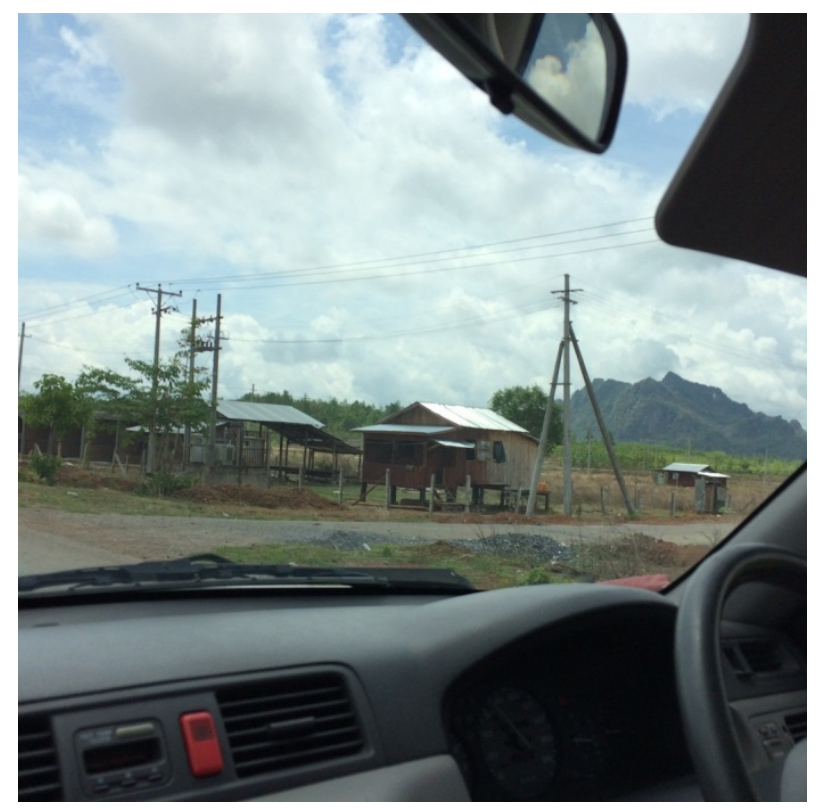

Photo 3. Entrance to the Kau Ku Village, one of the downstream villages of Hat Gyi Dam (Photo taken by Kyaw Thu Han)

Table 1. List of correspondents in different locations

\begin{tabular}{|c|c|c|c|c|}
\hline Correspondents & Locations & Male & Female & Total \\
\hline Villagers from the downstream communities & Kau Ku Village & 5 & 11 & 16 \\
\hline Villagers including head of village & Tadaroo Village & 6 & 12 & 18 \\
\hline Villagers including community leader, U Nyan Win & Mi Kayin Village & 5 & 16 & 21 \\
\hline Villagers & Mine Ku village & 8 & 11 & 19 \\
\hline Local NGO members working about the impacts of dams & Yangon & 4 & 4 & 8 \\
\hline
\end{tabular}


These four villages are situated about 70 kilometers downstream from the proposed Hat Gyi dam site, and about 15 kilometers North of Hpa-an, which is the capital of Karen State.

First of all, I went to the villages located in Hline Bwe Township and Hpa-an Township, which are the downstream areas of the construction of Hat Gyi Dam site. I went together with one of my research fellow, Saw John Bright since he is one of the local NGO called KESAN, helping these communities aware about these dams along the Salween. Whenever I arrived at a village, I informed to the village heads and interviewed with him so that I could get the baseline data of local population. I met with villagers currently living in the downstream areas and conduct the in-depth interviews with village including both women and men.

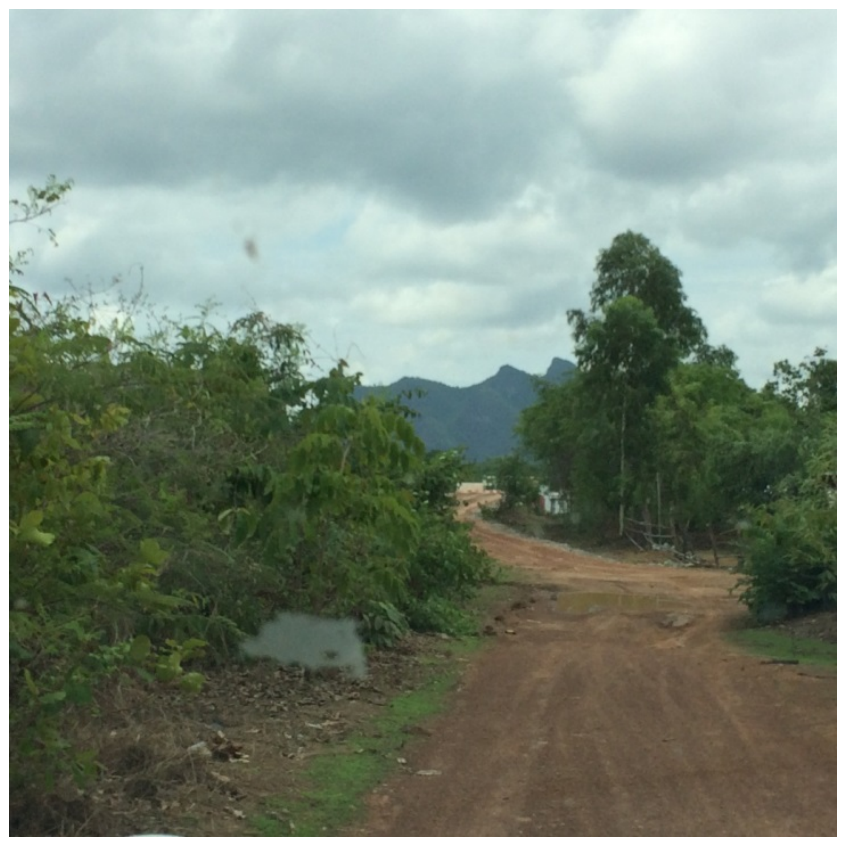

Photo 4. The Entrance to the Kauku Village (photo taken by Kyaw Thu Han)

I study how local people think or believe that the Hat Gyi Dam would affect their lives and livelihoods. What is their deepest concern for those who has lost their land and livelihood due to building large-scale dams? What are the current efforts of Local and international NGO or other authorities try to help these communities?

\subsection{Ethical Issues}

Ethical considerations are a very important to consider when conducting research to ensure that data collection does not put interviewees at risk. Before conducting interviews, I usually first gained the consent of respondents. And if I want to use their real name and photo in my paper, I told them and get their agreement. Otherwise I do not mention my respondents' names but only say like one farmer or one old woman from Kauku village or Tadaroo village.

The research conducted is about the possible socioeconomic impact of the Hat Gyi Dam, which is a politically highly controversial piece of infrastructure in the country. And the dam site is controlled by various ethnic arm groups as well as government army. Therefore, most of the people do not want to involve with such armed groups' affairs. So I have to ask permission from the participants before I make interviews or asking questions to them. The Informational introductory speech given to them explained the purpose of my research and the rights of the voluntary participants.

\subsection{Limitations}

As an urban living entry-level researcher from Yangon City conducting research in rural areas of Kayin State, Eastern Myanmar, I had both cultural and political limitations. Cultural limitations included occasional language barriers, and from time to time trust as a Burmese researcher. Another limitation to the research was the political controversy behind the Hat Gyi Dam, which added political risk to participation. Many Myanmar's military Battalions and Ethnic Armed Organizations (EAO) are stationed in the Hat Gyi dam vicinity made it impossible for this researcher to visit the project site and collect information from potentially affected communities in the dam flooding area. For this reason, this research only focuses on the potentially affected downstream communities. The method of sampling was a major limitation to the integrity of my research. I was researching as an outsider to the community with limited funding, a limited time frame, and with limited transportation and therefore utilized the convenience method of sampling. And I also could not go to the dam site due to the land mines on the way and many different military groups are obstructing on the way. As a result, convenience sampling sacrificed some of the statistical dignity of the research as a trade-off for safety and efficiency.

Another major problem for me is that even the key informants such as the head of villages do not know the exact number of population of their villages. And I cannot get the EIA document because the Hat Gyi Dam's Environmental Impact assessment (EIA) has not been made public by Thailand although it is normally obliged to do so by law) due to a former nondisclosure agreement signed between EGAT and the Myanmar Hydro Electric Power Department. (Journal of Water Resources and Ocean Science, 2013). That is the major weakness when I do the literature review.

\subsection{Conceptual Framework}

What is the livelihood?

Livelihood is defined as the means of securing the basic necessities -food, water, shelter and clothing- of life". Livelihood is defined as a set of activities, involving 
securing water, food, fodder, medicine, shelter, clothing and the capacity to acquire above necessities working either individually or as a group by using endowments (both human and material) for meeting the requirements of the self and his/her household on a sustainable basis with dignity. The concept of livelihood also relates to include social and cultural means, i.e. "the command an individual, family, or other social group has over an income and/or bundles of resources that can be used or exchanged to satisfy its needs.

\section{What Is Gender in This Research?}

Gender is not determined biologically, as a result of sexual characteristics of either women or men, but is constructed socially. It is a central organizing principle of societies, and often governs the processes of production and reproduction, consumption and distribution' (FAO, 1997). Although gender is not equal to women but generally accept that gender issues focus on women and on the relationship between men and women, their roles, access to and control over resources, division of labor, interests and needs. Gender relations affect household security, family well-being, planning, production and many other aspects of life (Bravo-Baumann, 2000).

All programs, policies and technical assistance to improve the lives of women in this region should be consistent with state's obligation to ensure that women and girls have equal tenure rights and access to land, fisheries and forests independent of their civil and marital status. I also want to raise the voices of farm-women living in Salween Basin community.

But unfortunately, in our country, local Community based organizations and activists usually assume that we do not have any gender inequality in our society. Indeed discrimination against women is deep-rooted and universal.

In my research, I also focus on making gender inclusiveness. I selected my correspondents to be more than half of them are female to ask about women's ownership of land, their difficulties and whether the impacts of hydropower dam fall equally or not on men and women.

\section{Results \& Discussion}

This section presents findings from qualitative, in-depth interviews and group discussions with four villages of downstream communities located on the south portion of Salween River in Karen State, Myanmar. The Objective of this section is to ask questions and examine the situations before the dam construction started and the possible outcomes of the dam from the perspective of local people. In order to do so, it will be divided into twelve questions and the responses of the local people to these questions and the analysis of these responses.

Not everyone has heard of hydropower dams, but consequences of the dam will affect everyone. In order to find out how, I first asked questions about people's general awareness about Hat Gyi dam and perception of the possible consequences of Hat Gyi dam. I then asked a series of questions about changes of livelihood, social condition and income if the construction of dam will finish. I also focus on the different consequences on the men and women.

\subsection{Research Sites}

My research sites are the communities living in Karen State on the downstream area of the Salween River that are expected to be affected by the Hat Gyi Dam. These include four villages in Hpa-an Township and Hline Bwe Township. The selection of these research sites is based on the safety of the researcher and availability of the local people in the affected area. I could not go the dam flooding area due to arm conflicts currently happening in the region.

\subsection{Background of the Three Potentially Affected Downstream Communities}

The location of the four downstream villages I went to namely Tandaroo, Kauku, Mine Ku and Mi Kayin villages, which are located inside Hlaing Bwe and Hpa-an Townships. The number of households in Tandaroo village is 256 , in Kauku village is 207, Mine Ku village is 135 and Mi Kayin is 476. (Source: village heads of these villages). "Hpa-an District, is a district of the Kayin State in Myanmar. It consists of 5 towns and 1490 villages. 2014 population was 783,510." (Source - Wikipedia). Hpa-an township has the total area of 1,119 square mile $(2,899$ square $\mathrm{km}$ ) and total Population is (2014 census data) 421,575 people and it is a part of Hpa-an District. Hlaing Bwe Township has the total population of 265,883 people and it is also a part of Hpa-an District. 


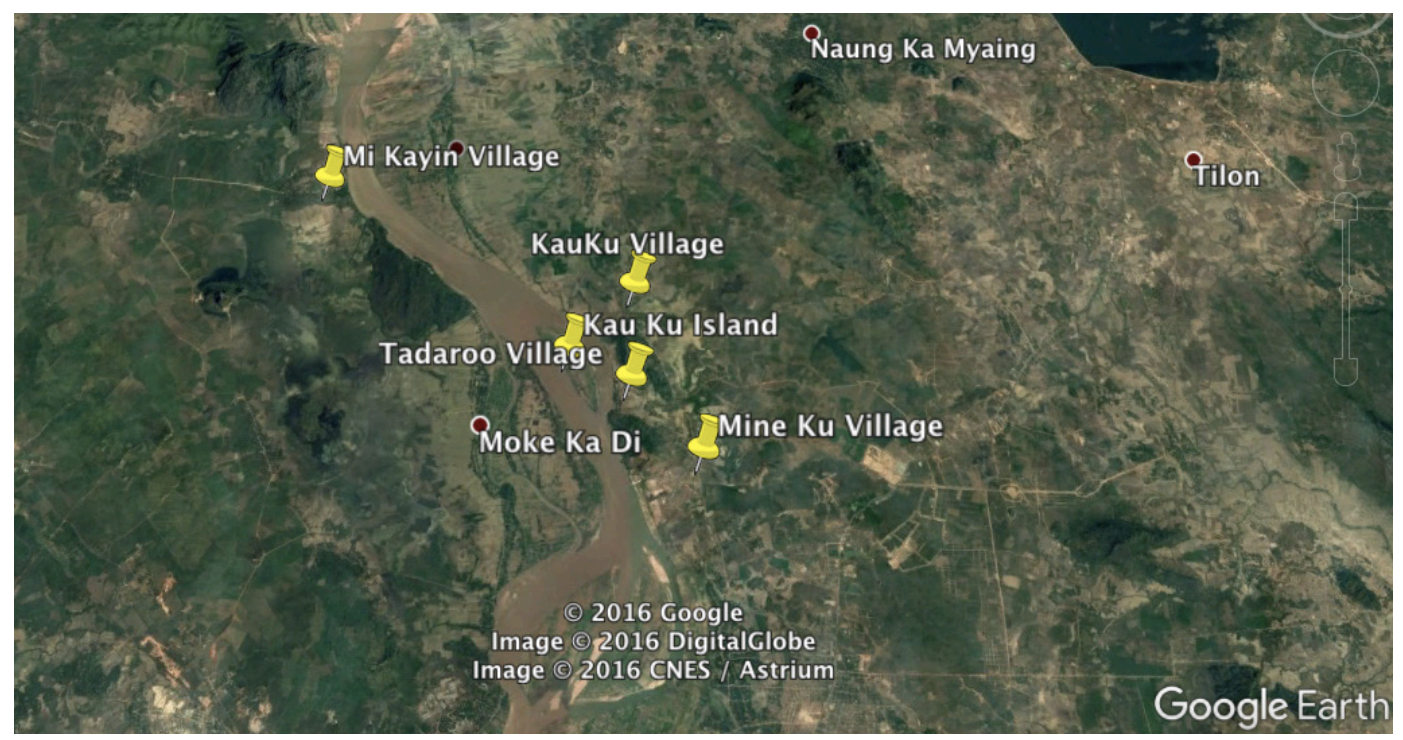

Figure 2. The map showing the four villages at the downstream area of Hat Gyi Dam (Source: Google Earth)

The populations of Tadaroo village, Kauku village, Mine Ku village and Mi Kayin are more than 1500 people, more than 1000 people, nearly 2000 people and more than 3000 people respectively. (Source village heads of these respective villages. Even they don't know the exact number of population in their villages and can say the rough number of populations)

The current livelihoods in Mi Kayin village are mostly paddy farming. Most of the villagers including men and women own or has the right to work in paddy farms.

(According to the 2008 constitution, the State owns all farming land and water resources, and the farmers only can have the Form 7 which means the right to work and pay taxes in the specific lands.)

The current livelihoods in these villages are very similar and mostly consist of paddy farming, vegetable planting and fishing. But the majority of the villager's livelihood relies on the paddy farming. Almost everyone living in these villages earns their living from farming including rice cultivation, vegetable growing, fruit orchards, rotational farming and fishing in the Salween River. Most of the people in these villages are Karen ethnic people.

"The current yield of paddy fields is around 60 baskets $^{1}$ of rice per acre in Tadaroo village.

"Our farm crop yields are not competitive to other villages which use fertilizers because we do not use fertilizers in our paddy farms and we only do single crop in one year" (U Saw Nyan Win, age 43, village head of Kauku village, Hpa-an Township)

People in Kauku village and Tandaroo village do only single crop during the rainy season. They do not do multi-crop like in other two villages. And then the rest of the year, some people do fishing and vegetable growing as extra income.

Rice is not just for family consumption. They have to sell rice in the market and buy other things they need in their lives.

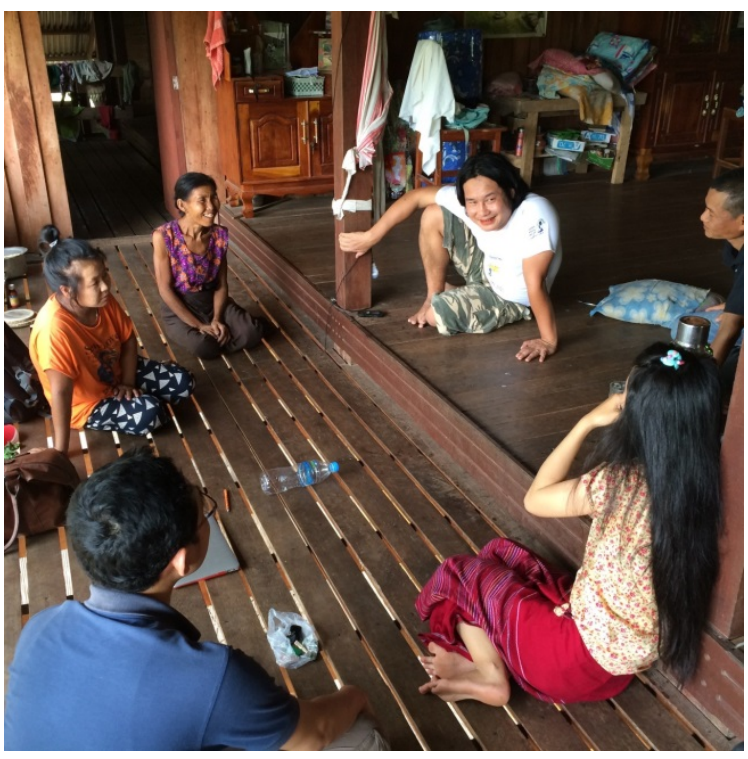

Photo 5. Group discussion with the local people in the Tadaroo Village" (Photo taken by Kyaw Thu Han)

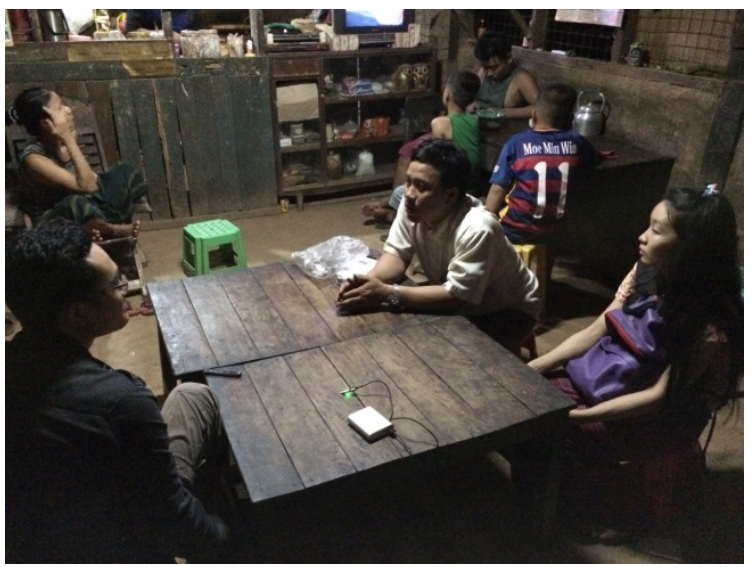

Photo 6. "In depth interview with the village head of Mine Ku village" (photo taken by Kyaw Thu Han) 


\subsection{Questions and Results}

\section{Question 1}

Have you ever heard of the Hat Gyi Dam? Yes or no.

91\% of the respondents have heard of the Hat Gyi Dam. Nearly the entire respondents were aware of the Hat Gyi Dam. This indicates that the Dam is well known in the downstream communities. I speculate that awareness of the Hat Gyi Dam is high due to its controversial status in the media during construction proposal and due to the awareness campaigns of local NGOs like KESAN or KHRG to make them aware. It also indicates that the majority of the results are viable having respondents largely aware of the dam.

But some respondents say they do not know the name the dam Hat Gyi and they don't know the location of the dam as well. They only know there will be dams on Salween River and it may pose danger to them. Only a few people do not know about hydropower dams at all.

Question 2

$94 \%$ of the total respondents responded to this question. $6 \%$ of the total respondents preferred not to answer this question. Of the $94 \%$ who responded to the question, $24 \%$ answered uncertain and 76\% answered negative.

It means most of the respondents have negative attitude toward the dam. Still, a fourth of the respondents found the dam to be unsure or does not want to comment. The fact that one fourth of people preferred not to answer the question demonstrates the controversial nature of the dam and the hesitant nature of the local people to speak out about it.

"There are lots of arm groups in the region now, in the past there are only KNU and DKBA forces in the region. Now many militias and border guard forces are in the region and sometime fighting between armed groups occurred." (A farmer from Mine Ku village, downstream communities in Kayin State)

Some respondents said that talking about dam will disrupt their current peaceful situation and so they want to avoid talking about it because the armed groups have become Border Guard Forces (BGF) which is directly controlled by the government Military in the country who favors and signed the Hat Gyi Dam project.

\section{Question 3}

What are the current livelihoods of people living in downstream areas of the Hat Gyi Dam? How much they rely on the Salween River?

Answers: paddy farming, rubber farming, fishing, raising animals

$72 \%$ responded paddy farming, $8 \%$ responded rubber farming, 20\% are fishing and they all said that all forms of livelihood mainly rely on the Salween River, its tributaries and its ponds. So it is important for them to get the undisrupted water from Salween. For farmers, they do not use the fertilizers like in other areas of the country. But they rely on the sediments contain in the Salween River.

"By relying on the Salween River, they can send their children to school, they can donate occasionally, they can meet their family needs etc. their whole lives depend on the river." (A farmer from Mi Kayin Village, Hline Bwe Village, Kayin State)

"When the fishermen go fishing in the Lake, their wives went together and help them. After that the wives sell the fishes in the market." (A single woman from Mi Kayin Village, Hline Bwe Village, Kayin State)

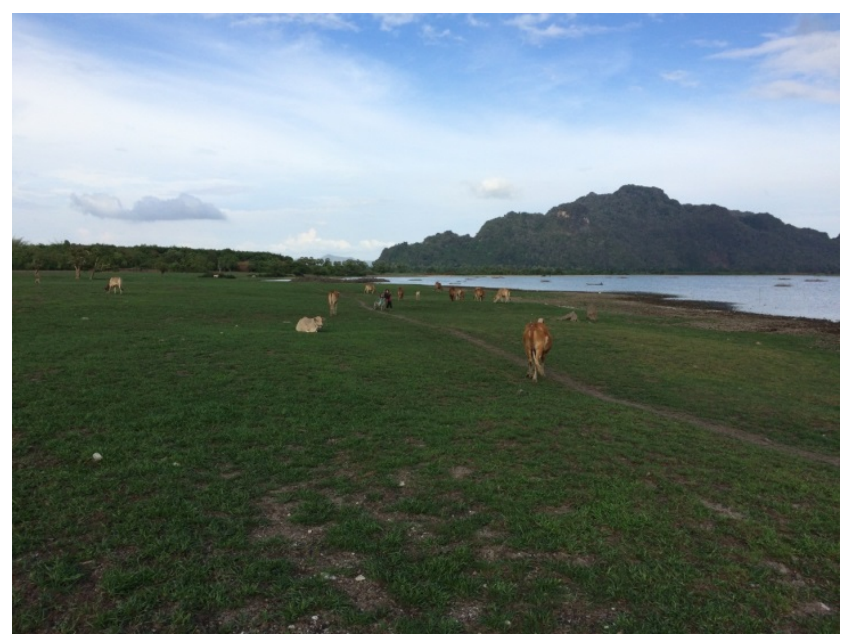

Photo 7. The pastureland near the Mi Kayin village (31.3.2016) Photographer - Kyaw Thu Han

Question 4

What is the situation of food security, availability of food, in the area?

Most of the respondents said they have enough food security now. They can get rice, oil or vegetables by growing themselves and they can get meat by raising pigs, ducks, chicken or goats. So they are self-sufficient for food and with the extra income they can buy other things they need. It means the current livelihood situation before the dam is built is good enough for the local people but they worry about the potential consequences on their food security and availability of food in their villages.

"We only need to buy salt from the market. That's the only we cannot make because we are far from sea. Everything else we can grow ourselves. Rice, oil, meat or vegetables are available to us and no need to buy for them." (U Kyaw, head of Mine Ku village)

\section{Question 5}

What is the situation of land ownership in general and women's land ownership?

Most of the respondents answered they own a few acres 
of land from 3-4 acres to 8-9 acres. Women also have separate ownership of land even they are married to men. They have separate ownership form and tax payment to the government. But ownership means that they have the form-7, which does not guarantee the ownership but only the right to work in the land or the green book, which is the tax receipt book. It is evident that they give tax to the government. So from those responses, we can know the land ownership between men and women in this region are not very different.

"Most of our villagers have at least 3 or 4 acres of land, and some rich families have more than 15 acres and my wife own some acres of land in her name too" (U Saw Nyan Win, age 43, village head of Kauku village, Hpa-an Township)

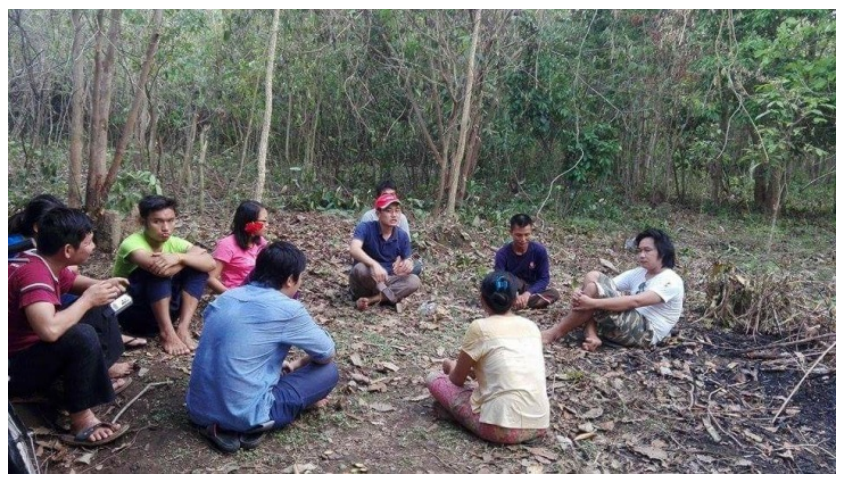

Photo 8. Group Discussion in a farm near Daw la Lake (photo taken by Aye Aye Myaing from Kesan)

Question 6

What is the situation of electricity availability in your region?

More than half of respondents $(60 \%)$ said they have electricity and $40 \%$ do not have electricity. Among who said electricity most of them $(72 \%)$ are getting the electricity by themselves by using own solar panel and battery. $(20 \%)$ of the respondents were unsure of the purpose of the dam. This is likely due to the confusing media surrounding the dam during construction and an overall lack of transparency for the project. Also, since there is no real correlation with their availability electricity and construction of dam, some of the population may assume that electric generation is not the purpose. They point out that the villages near the famous Lawpita hydropower dam which is the first dam in Myanmar did not get the electricity. Currently the electricity available to the villagers is very low and all the villagers want electricity although most of the local people are against the proposed hydropower dam.

Myanmar has also low electrification rate in the region. Research shared at a workshop in Yangon with government officials, private sector and civil society organizations shows that, at most, only 34 per cent of the population has access to grid quality electricity, and 38,000 villages have no electricity at all. (International Institute for Environment and Development)

One of the local men explained about his feelings;

"We cannot accept that the by going against the hydropower dam (i.e. Hat Gyi Dam), we cannot have the access to the electricity. Indeed, this is the duty of the government to provide the basic needs of the people such as electricity." (A man from Mi Kayin village)

\section{Question 7}

Are you satisfied with the current situation? Why?

The answers are yes they are content with the situation because they believe that the construction of dam is halted due to the new government policy. They do not aware the real situation of dam construction which is indeed still pending stage.

In the past decade, downstream villages of Hat Gyi dam have undergone a period of change and development. On 12 January 2012, Myanmar government has signed a ceasefire deal with the Karen National Union (KNU) which is the first written ceasefire agreement in 63 years. After the agreement signed, the villages in these downstream areas get the peace for the first time in many decades.

After the 2010 election, the new quasi-military and democratic government has been formed in 2010. The country has developed a slightly more democratic system of governance, opened up the economy to foreign investment, made some improvements in press freedom and made progress with peace agreements between ethnic groups including the KNU and other Karen ethnic armed groups. So the people in southern part of the country feel better and content with the situation but their only concerns is the proposed large-scale infrastructure projects such as Hat Gyi Dam on Salween River.

One of the local women highlighted about their situation in the following manner.

"Now the living situation is like in Heaven compare to the situation in the past when the civil war was happening in our region. We believe in new government that they will not destroy the current situation by building the (Hat Gyi) dam." (An old woman from Mine Kuu Village, Kayin State)

\section{Question 8}

What will be the greatest impact for both men and women when the dam construction is finished?

Most of the respondents said there would be many consequences on them economically and socially. Sixty-two per cent claim the dam will affect their ability to earn money due to the decrease in agriculture production. They believe that the sediments in the Salween river is very fertile and valuable for the farming and agriculture production.

"The sediments of Salween River is so fertile and our 
farmers have to rely on the quality of the water for our paddy farms." U Kyaw from Kau Kun Village)

They point out that due to the sediments of Salween River, they do not need to use the fertilizer in their farms. And if the dam is in operation stage, then they believe that the sediments would be fewer than before and will have big impact on the crop yield of the farms. Another impact they mention is the availability of drinking water will be reduced.

"We will have a lot of sufferings and a lot of consequences. Buts we rely on the river for our food and drinking water. So the biggest impact will be loss of available water in summer and consequently will impact on agriculture and fishing." (A middle-aged woman from Hline Bwe Township, Kayin State)

\section{Question 9}

What will be the livelihood situation in the downstream communities after the dam construction is completed?

Most of the respondents said if the dam construction is completed and it would affect their agriculture production, it would affect their fishing jobs etc. Therefore they couldn't survive by relying on farming or fishing or other local works, which rely on the river alone. So they have to adapt the situation of lower income. Most of the able people, both men and women, will go to towns or abroad to find a work. It means they lost their former livelihoods and tries to survive on other means. Some might go to Thailand to work there. People in these areas do not hear any employment program after the dam is built.

"There will be only children and elder people in the villages, the rest of the population have to go to other places for income and livelihood. The family will disintegrate and children education and health situations will be compromised." (A woman from Mi Kayin village, Hline Bwe Township, Kayin State)

\section{Question 10}

Do they feel confident about handling of the Hat Gyi dam by the authorities after it will be built?

$70 \%$ of the respondent said they worry about the malfunction of dam or the dam might collapse due to some kind of natural disaster such as earthquake resulting in the catastrophic flooding in the downstream areas. And 30\% of the respondents said they believe the dam site is located on the earthquake fault line. It may be related to mistrust of government for years of civil war and oppression. Whatever the reason for such a high level of concern, it is obvious that communities at close proximity to the Salween River would be concerned if a dam were built upstream.

"In the past the military government use the "Four Cuts Policy" to control our Kayin people. Now they will use the
(Hat Gyi) dam to control us." (a man from Kyondoe Township, Kayin State)

\section{Question 11}

Do you feel threatened by the Hat Gyi Dam's location upstream from your community? And what are your biggest concerns?

A majority of the population has a concern that the due to the Hat Gyi Dam the water will not flow enough and their agriculture production will be damaged. Due to the interest of conflicts, the dam may initiate a new arm conflict within the region.

$39 \%$ of the respondents responded that they couldn't fish anymore. Although most of the local people are not fishermen, people usually fish in the tributaries of Salween.

$20 \%$ say their underground water source will deplete or reduce due to the dam. They pointed out that in the summer of 2016 the unusually severe hot season for the country, the water level of their well reached so low and some well depleted.

People in Downstream villages of Hat Gyi dam worry about the vulnerability to a wide range of slow and rapid onset natural hazards, including floods in the rainy season, droughts in the summer. They worry about earthquakes can destroy the dam because the location sits on the earthquake fault line. They do not like the most "at-risk" region in the country due to the dam built on their upstream.

\section{Question 12}

What is the response from government authorities or other local NGO to listen to the concerns of local people?

All of the respondents said there is not any kind of engagement from government in this matter. They do not even inform to the general public about the dam directly. They only called a private meeting with local village administrators and inform about the dam. But either local authorities or higher-level officers do not engage about the issues of possible consequences of dam. Most of the respondents $(72 \%)$ said they only aware about the planning of dam through the local NGO, KESAN that are actively campaigning against the dam construction although KESAN do not have the project impact assessment document. But again no other NGO has come to inform or consult with the local communities for the possible consequences of Hat Gyi Dam.

"The idea of the heads of villages is like that. The higher authorities will decide this dam issue, so whatever they decided; there is nothing they can help to stop it. So they ignore it completely. For the NGOs side, there is no NGO that is currently doing for dam issue in their region except KESAN (a farmer from Mi Kayin Village)

\section{Question 13}

What would you like the government authorities or NGOs to do for the possible consequences of the dam? 
The majority of people in downstream villages of Hat Gyi dam point to the need for more support from institutions such as local and national governments and NGOs. Current household and community actions can be amplified by highlighting how and where people can get support, connecting them with local government institutions and NGOs operating in their area. They said they want to hear more about the dam and want to understand to clear the confusion around the dam. Since they do not have enough information due to lack of good communication, numerous rumours are spreading and they don't know what to believe. They also want to talk about their concerns and they want the higher authorities of state or central level government to listen their concerns. They want consultation workshops or public hearings about the Hat Gyi dam initiated by either from government authorities or NGOs. Although they are aware of the dam building process, they do not feel confidence that they know the details of the dam. As we seen in the above question, in downstream villages of Hat Gyi dam, awareness of the dam was very high: $91 \%$ said they had heard of it. However, awareness of this dam did not reflect higher understanding of it. Only $35 \%$ of people felt confident that they knew the actual consequences of the dam on them.

"We don't know who to contact or raise our concerns about the dam. Nobody including government or NGO comes to us" (a woman from KauKu village from Hline Bwe Township, kayin State)

\subsection{Opinions of Local People on their Possible Livelihood Changes}

Based on the results of the discussions and interviews, the local economy will be very negatively impacted by the Hat Gyi Dam.

"A dam also holds back sediments that would naturally replenish downstream ecosystems. When a river is deprived of its sediment load, it seeks to recapture it by eroding the downstream riverbed and banks (which can undermine bridges and other riverbank structures, as well as riverside woodlands)." (International Rivers, n.d.)

For businesses that use the Salween River directly, changes in hydrology and water quality if the dam is completed constructed. Based on these responses, the local people firmly believe that the Hat Gyi Dam has had a very negative impact on the local economy and livelihood. If they adapt these situations by changing livelihood such as going to Thailand or other towns, the social impact will be very high on the local communities. If the men go abroad for jobs then the responsibility to care the remaining elders and children will rest on the women. In Myanmar, usually it is women who bear the responsibilities and burdens of taking care of the family and in many ways safeguard the livelihood of the household. So clearly, damages caused by hydropower projects will be more intensely felt by women. Most of the communities rely on the Salween and its tributaries to get fish for their livelihood.

\section{Conclusions and Recommendations}

Communities are centered around rivers and other bodies of water because they rely on the water as a resource. A dam interrupting a river leads to unpredictable social impact. The downstream communities of Hat Gyi dam rely on the Salween River as their major source of livelihood. The current situation for them is very satisfactory and they worry so much about the possible socio economic consequences of the dam on them. Their livelihoods such as farming and fishing will be affected by the proposed dam construction. Besides, they do not have any place or platform to voice their concerns. They do not have the proper channel to communicate to the respective authorities. The most important outcome of this research will be the potential to mobilize both local communities and civil societies to consider further detail socio economic consequences on the downstream communities and found a proper communication channel so that the local people can raise their concerns. Historically, the social and economic impact of dams has been overlooked and underestimated in our country. And Government usually hushes the voices of people by various means not only in this Hat Gyi Dam case but also in other issues as well. The significance of the finding is that this research paper shows that a large infrastructure project, being the Hat Gyi Dam, will place externalized social, environmental, and economic costs on the downstream communities. Responses to the questions I asked show perceived negative consequences from the Hat Gyi Dam on many things including the vital parts of the people such as livelihood, water source, and social cohesion. The majority of people in downstream villages of Hat Gyi dam point to the need for more support from institutions such as local and national governments and civil societies.

Moreover, close attention needs to be paid to the relationship between gender inequality and the consequences of dam projects. In Myanmar, it is women who bear the responsibilities and burdens of taking care of the family and in many ways safeguard the livelihood of the household. As we found out in question 6, the women are not even invited to the consultation meetings. Indeed women who are largely responsible for household chores which are linked to natural environment, they do not have decision making power and currently, Myanmar laws afford little protection for women whose human rights may be impacted by hydropower projects. So clearly, damages caused by hydropower projects will be more intensely felt by women of the downstream communities. Indeed, the ability to improve the situations of local women displaced by hydropower projects (or others) relies entirely on 
addressing the gender inequality. Many questions still need to be examined in order to expose the answers and evidence that will convince local and international organizations to place more importance on the need to reduce gender inequality.

\subsection{Recommendations for Further Studies}

How can good communication strategy be drawn to give information about the hydropower dams to the local people?

Giving clear access to information is the first step for local people in the area to be meaningfully involved in decision-making. Currently, local people in these downstream communities are barred from accessing information about projects such as the Environmental Impact Assessments or other useful fact and data about the dam.

Media and communication have real potential to support people to understand the impact of changes in weather on their lives. They can help people build awareness, motivation, self-belief, knowledge and skills to enable them to take action. They can support communities to discuss common issues, work together, influence public policies and hold leaders to account. This, in turn, can contribute to stronger long-term systems to support the public. So my first recommendation for further research is to conduct how to communicate effectively to the downstream communities about the potential consequences of the dam or any useful facts and data about the dam. According to the answers of the people in this research, the researchers for EIA report of the Hat Gyi dam did not come and survey the situation of downstream communities. But clearly the cost of hydropower dams will also affect them too. So another recommendation is to research about the different ways of raising concerns by the local people. Civil societies should also point the weakness in the EIA SIA process in large-scale infrastructure projects like the Hat Gyi Dam. Although the civil societies organizations (CSO) have some activity against the dams building on Salween River, the communication to the local people is still weak. So they should focus more on communication about the dam and its consequences.

My research report on the possible consequences of the Hat Gyi hydropower dam is just the beginning. The research can be built on. For instance, people can use my research questions and responses to conduct their own surveys. This will enable tracking of key responses over time, which will enrich understanding of the role of communication and local NGOs in the region for accepting or campaigning against the dam projects in their region.
List of Interviewees from Civil Societies Organizations in my in depth interviews

Naw Htoo Linn Phaw (a.k.a Jasmin) from Karen Human Right Group (KHRG)

Naw Eh Thaw from Karen Human Right Group (KHRG)

Aye Aye Myaing from Karen Environmental and Social Action Network (KESAN)

Saw Thar Poe from Karen Environmental and Social Action Network (KESAN)

Saw John Bright from Karen Environmental and Social Action Network (KESAN)

Saw Alex from Karen Environmental and Social Action Network (KESAN)

\section{Acknowledgements}

I would like to firstly recognize the benefits of MK 31 program. This program taught me much about writing a research thesis paper, how to collect data, and how to analyze these raw data and information. And I also want to say thanks to the program manager Dr. Carl Middleton, my mentor Ajarn Chantana, program Coordinators Thita and Orapan and the financial support throughout my whole research period.

More importantly I like to say thanks to the local people who live in the downstream areas of the Salween River who made my research paper possible. I also like to thank many NGOs and local organizations working in this field that help me to reach out to the local people and necessary translation from ethnic language to my language.

\section{REFERENECES}

[1] Karen Human Rights Group's report “With only our voices, what can we do?, Land Confiscation and local response in southeast Myanmar" June, 2015

[2] International Rivers. (n.d.). "Environmental Impacts of Dams" from

https://www.internationalrivers.org/environmental-impactsof-dams

[3] "Water Grabbing/ land grabbing in shared water basins the case of Salween River Hatgyi Dam"

[4] Salween Watch. The Salween River, [Online]. 2011a. Available from: http://www.salweenwatch.org/index.php

[5] E. Zerrouk, Journal of Water Resources and Ocean Science

[6] http://www.sciencepublishinggroup.com/j/wros 